\title{
INTERNATIONAL AIR TRAVEL AND FDI FLOWS: EVIDENCE FROM \\ BARCELONA
}

\author{
Xavier Fageda \\ (University of Barcelona)
}

Address: Department of Applied Economics, University of Barcelona. Av. Diagonal 690, 08034 Barcelona (Spain). Tel. +34934039721. Fax.+34934024573. E-mail: xfageda@ub.edu

\begin{abstract}
This paper provides a bridge between the literature examining the economic impact of air services and the literature analyzing the determinants of bilateral FDI flows. I estimate a gravity equation for the determinants of bilateral FDI flows between the Spanish region of Catalonia, home to the airport of Barcelona, and countries of all over the world for the period 2002 through to 2015 . I find evidence that the reduction in travel time due to the availability of non-stop flights scheduled with sufficient frequency increases the amount of FDI due to the enhanced transmission of information.
\end{abstract}

Acknowledgments: I am grateful to all the comments received during the Workshop entitled Infrastructure and the spatial organization of economic activity in Madrid (Spain). I am also grateful to Prof. Jens Suedekum and two anonymous reviewers for their very helpful comments. I acknowledge financial support from the Spanish Ministry of Economy and Competitiveness (ECO2015-69193-R)

Keywords: international air travel, foreign direct investments, gravity equations JEL codes: F21, R10, R40 


\section{INTRODUCTION}

The role of air transportation as an engine of economic growth for regions and cities has been extensively analyzed and, in a continuation of this line of research, this paper seeks to provide fresh insights into the economic impact of this mode of transport by examining the influence of non-stop air services on foreign direct investment (FDI) flows.

In this regard, several studies have found evidence that FDI contributes to economic growth (e.g, Alfaro et al., 2004; Baltabaev, 2014; Borensztein et al., 1998; Ford et al., 2008; Iamsiraroj, 2016; Leichenko and Erickson, 1997; Newman et al., 2014; Wand and Wang, 2015). FDI may be an important vehicle for the transfer of technology and innovations. Furthermore, it may improve the access to foreign markets and the financial conditions of target firms. Hence, FDI flows are frequently associated with productivity gains, an improvement in export performance and more financial resources for the economies that take benefit from them.

To examine the link between air services and FDI, bilateral investment data between the Spanish region of Catalonia, home to the airport of Barcelona, and countries of all over the world are exploited for the period 2002 through to 2015.

I estimate a gravity equation for the determinants of bilateral FDI flows and consider all the relevant factors that account for them. The econometric analysis specifically takes into account the unique feature of the dependent variable, that is, it constitutes a zero-inflated continuous variable with extreme values. Additionally, the analysis takes into consideration the potential endogeneity bias resulting from the simultaneous determination of air traffic and FDI flows. I perform several robustness checks reporting results of regressions with different techniques, instruments and control factors, distinguishing between inward and outward investments, and using different samples of destination countries and origin regions. 
For the purposes of this analysis, the case of Barcelona is especially pertinent as it has benefited from an extraordinary increase in the number of flights over the last decade. A necessary condition for this increase has been an external shock, namely, an expansion of capacity achieved with the opening of a new runway in 2004 and the inauguration of a new terminal in 2009. However, this increase needs to be placed in the broader context of the general globalization process experienced by the international air travel market in recent years in which an increasing number of airlines offer flights to airports located far away. In this regard, the airport of Barcelona is one of the ten largest airports in Europe, being the largest non-hub airport in Europe along with secondary airports in London (Gatwick) and Paris (Orly).

The availability of non-stop flights, scheduled at a minimum frequency, improves substantially the ease of communication between the territories involved, reducing at the same time the costs of doing business, since the shift from 'not having' to 'having' non-stop flights can reduce travel times by 30 percent or more. The main hypothesis tested in this paper is that the reduction in travel time due to the availability of non-stop flights, offered at a sufficient frequency, increases the amount of FDI because of the enhanced transmission of information.

Various studies have undertaken empirical analyses of the causal relationship between air traffic and measures of urban or regional economic performance, such as, employment, income or number of firms, using samples of U.S. urban areas (Bilotkach, 2015; Brueckner, 2003; Green, 2007; Sheard, 2014) or European regions (Albalate and Fageda, 2016; Bel and Fageda, 2008; Percoco, 2010). A major shortcoming of these studies, however, is that they all use aggregate data to account for the economic characteristics of the territories under study and aggregated airport traffic. However, the economic effect of air services is related primarily to enhanced connections to specific destinations. Thus, previous studies fail to address the economic effects associated with individual routes. 
Here, I opt to analyze the impact of international routes on investments by foreign companies, while previous studies focus their attention on local employment effects attributable to airport size. Note that air traffic may have different economic effects on its urban area or region, so that an expanding airport might increase the number of employees directly or indirectly or, alternatively, increase the number of tourists. Additionally, air traffic can facilitate face-to-face contacts thus facilitating the delivery of tradable services and increasing the attractiveness for business investment. This latter effect can be captured most appropriately by referring to bilateral air traffic data.

Furthermore, recent studies of the economic impact of transportation (eg; Duranton and Turner, 2012; Sheard, 2014) use historical data to circumvent the potential endogeneity bias due to the simultaneous determination of traffic and growth. However, analyses of bilateral flows may enable us to identify instruments that are much less information demanding than is the case when working with historical data. In particular, I use flight data from the destination country to other airports rather than Barcelona.

The role of transportation costs as a determinant of FDI has been explicitly considered in studies that examine the trade-off between investments and trade which affect firms involved in international activities (Blyde and Molina, 2015; Brainard, 1997; Daniels and von der Ruhr, 2014). ${ }^{1}$ The focus of these papers is on the lower costs of transporting cargo and the analysis is made using data at the country level. Here, however, I consider commercial air services for personal travel. Thus, the potential increase in investment that I seek to capture is

\footnotetext{
${ }^{1}$ Note that the relationship between a parent company and its subsidiary may be horizontal (the parent and the subsidiary produce the same good), or vertical (the subsidiary produces an input for the parent). In this regard, the purpose of horizontal FDI is to replicate production facilities abroad to improve access to foreign markets, while the purpose of vertical FDI is to break up the production process to benefit from lower production costs.
} 
not related to lower cargo transport costs but rather to more convenient trips that can promote face-to-face communication between firms' employees, which in turn may lower monitoring and information acquisition costs for investors. Furthermore, I use data at the regional level for one of the endpoints.

As such, this paper serves as a bridge between empirical studies examining the territorial economic impact of air services and those concerned with the determinants of bilateral FDI flows. The contribution of this paper to the previous literature is that it provides an explicit empirical test for the causal relationship between air services and FDI bilateral flows. Two clear implications of my results are that they offer new evidence of the positive externalities associated with airport capacity expansions, and provide arguments for the lifting of bilateral agreements that still regulate air traffic between most countries in the world. Furthermore, the results of my analysis should provide fresh insights into the impact of innovations associated with electronic communications and the prevailing relevance of transportation to facilitate face-to-face contacts.

Two closely related studies are Giroud (2012) and Hovhannisyan and Keller (2015). Giroud (2012) uses data from the U.S. manufacturing sector to show by means of a difference-in-differences analysis that new airline routes bring about an increase in investments within firms and an increase in a plant's total factor productivity. Essential to the interpretation of his results is the existence of asymmetric information and agency problems in the relationship between plants and headquarters. Hovhannisyan and Keller (2015) report a significant positive impact of U.S. business travel to foreign countries on patenting rates and conclude that face-to-face communication is crucial for transferring technology. The authors argue that their results are consistent with the evidence obtained from surveys that suggest 
that business executives prefer face-to-face meetings to phone or web-based communication. ${ }^{2}$ While the idea underpinning my analysis is similar to the ideas analyzed in these two studies, these authors do not provide a direct link between air services and FDI.

The rest of this paper is structured as follows. In the next section, I explain the data and methodology used to test the relationship between air services and FDI flows. Section 3 analyzes and discusses the results, Section 4 provides several robustness checks and section 5 contains the concluding remarks.

\section{DATA AND METHODOLOGY}

\section{Sample}

The data used to analyze the determinants of bilateral FDI flows are generally at the country level, as data at the urban or regional level over a long time span are hard to obtain. However, the analysis of the impact of international air travel on bilateral FDI requires the use of urban or regional data, at least for one of the two endpoints. Ideally, I should use data of FDI flows between regions of different countries but I only have available data of FDI flows from regions in Spain to countries of all over the world.

The two largest cities in Spain, Madrid and Barcelona, concentrate more than 70 per cent of FDI with origin or destination from/to this country. Furthermore, international air travel in Spain is concentrated in Madrid, Barcelona and tourist destinations. ${ }^{3}$ Thus, a sample based on all Spanish regions would not be helpful for the purposes of my analysis as many

\footnotetext{
${ }^{2}$ Note, that face-to-face contacts and electronic communications may be seen as complements or substitutes, although they are not necessarily equivalents (Gaspar and Glaeser, 1998; Storper and Venables, 2004).

${ }^{3}$ Medium-sized cities as Valencia, Bilbao or Seville only have international direct services to the largest cities in Europe like London or Paris. Obviously, international air travel from/to tourist destinations like Canary or Balearic islands is generally not for business.
} 
observations would take the value zero for the two key variables (FDI flows, international air services).

I could make the analysis for Madrid and Barcelona but I prefer to focus in one region to have a more homogeneous sample in terms of the region of origin. Since the econometric analysis exploits the variation between countries, the joint consideration of Madrid and Barcelona as regions of origin would have the practical problem that the values of most of explanatory variables (which refer to attributes of the destination countries) would be the same for Barcelona and Madrid.

Note that Madrid is the political capital of the country and headquarters of most of large Spanish firms are located there. Furthermore, the airport of Madrid is the hub of the former Spanish flag carrier. Hence, the proportion of connecting passengers over total passengers is very high in such airport.

Taking this into account, the baseline regressions exploit a data set that includes FDI flows (both inward and outward) between all countries in the world and the Spanish region of Catalonia, home to the airport of Barcelona. The analysis of the relationship between FDI and air services for Barcelona will not be affected by the "headquarters" or "hubbing" effect. However, as a robustness check, below I show results of a regression with Madrid as the Spanish region of reference and of regressions with the joint consideration of Barcelona and Madrid as regions of reference.

Regarding the countries with FDI flows to/from Barcelona, I focus on the following geographical areas: European Economic Area, North America, Latin America and the Caribbean, the Middle and Near East, the Far East, the Maghreb and the former Soviet Union States. I exclude the Sub-Saharan African countries from the analysis as this would add considerable heterogeneity to the sample given their much lower level of development. Note also that the inclusion of the Sub-Saharan African countries might bias the results (in favor of 
my hypothesis), since this would mean including in the dataset many countries with no direct flights to Barcelona and very modest (if any) flows of investment. In fact, bilateral air agreements between Spain and many Sub-Saharan African countries do not allow flights to Barcelona.

\section{Insert Table 1 about here}

Table 1 show the countries included in my sample. From the geographical areas considered, I exclude those countries with no significant FDI flows with Barcelona in any year of the period considered. Overall, my sample includes 81 countries with data for the period 2002-2015 amounting to 1134 observations. All the major economies of Europe, America, Asia, and north of Africa are included in the analysis and almost 100 per cent of FDI with origin or destination in the region of Barcelona are considered in the analysis. As a robustness check, I will also report results of a regression that exclude the countries that are members of the European Union (EU), a regression that exclude countries that have non-stop flights to Barcelona through several cities, and a regression that excludes observations with zeros in FDI flows and air frequencies.

The largest amount of bilateral investment flows having Barcelona as source or destination include countries of the European Union such as France, United Kingdom, Netherlands, Germany, Italy, Portugal and Belgium. It also includes United States, Switzerland, and Latin American Countries such as Mexico, Brazil, Argentina and Colombia. Other countries with large bilateral investment flows with Barcelona include Morocco, Hong Kong, Japan, China, India, Israel, Turkey and Russia. In contrast, some countries do not have bilateral investment flows with Barcelona in several years of the considered period. Among these countries, we can find small countries from the European Union (Latvia, Lithuania, Estonia), former Soviet Union States (Armenia, Belarus, Georgia, Uzbekistan), countries from Central America (El 
Salvador, Guatemala), Middle East (Saudi Arabia, Jordan), Far East (Indonesia, Malaysia, Philippines, Sri Lanka, Thailand) and North of Africa (Mauritania).

The number of passengers in the airport of Barcelona has moved from 21 million in 2002 to 39 million in 2014, with a mean annual growth of 7 percent. In the considered period, the connectivity of the Barcelona airport to non-EU destinations has increased substantially with more than 20 additional destinations, including cities like Bogotá, Beijing, Doha, Dubai, New York-Newark, Miami, Montreal, Philadelphia, Sao Paolo, Singapore and Toronto. In this time there has been a remarkable increase in the number of passengers to Morocco (687 percent), Sweden (374 percent), Turkey (369 percent), Algeria (311 percent), Russia (275 percent), the U.S. (272 percent), Portugal (150 percent), France (142 percent), Italy (135 percent), Switzerland (117 percent) and Germany (99 percent).

The public firm AENA manages all the airports in Spain as a monopoly. ${ }^{4}$ All revenues of this firm come from charges paid by airlines and from commercial activities undertaken in their facilities so that it does not receive subsidies from the government. The integrated management implies the existence of cross-subsidies from large (and profitable) airports to small airports (with financial loses). Thus, the main goal of the airport operator in Spain is to sustain the smaller airports rather than generate positive externalities in big cities.

In this regard, the airport of Barcelona is one of the most profitable airports of AENA so that its investments are self-financed. ${ }^{5}$ Hence, investments in the airport of Barcelona at a time that was severely congested may be explained by the expectations of more passengers

\footnotetext{
${ }^{4}$ AENA has been partially privatized in 2015 .

5 Financial information of Spanish airports can be found on this website: http://www.aena.es/csee/Satellite/Accionistas/es/Page/1237569009199/1237568522644/Cuentasanaliticas.html
} 
(and the associated revenues) and these passengers may travel for a great array of purposes. Hence, such investments should be exogenous to FDI flows.

\section{Main variables and methodology}

The empirical strategy is based on the estimation of an equation that accounts for the determinants of FDI flows between Barcelona and the destination countries. The strategy employs gravity models, which are frequently used to analyze bilateral trade flows and which have recently been applied to the study of bilateral FDI flows between countries. ${ }^{6}$ In gravity equations, FDI flows depend on the size of both economies and the distance between them.

The definition of FDI flows in my dataset adheres to the guidelines of the 5th Balance of Payments Manual ( $5^{\text {th }}$ edition) compiled by the United Nations, ${ }^{7}$ where direct foreign investments are regarded as those in which the investor expects to control or influence the management and administration of a company operating outside the territory in which the investor resides. This includes participation in unlisted foreign companies, participation greater than 10 percent in listed foreign companies and the establishment or expansion of branches of foreign companies. It also includes large investments by special entities (foundations, cooperatives, economic interest groups) except operations by entities holding foreign securities, i.e., holding companies whose goal is to maximize tax strategies within the same business group. Here I focus on total FDI flows between the region in which Barcelona airport is located and the destination (or source) country because my primary concern is the impact of air transportation on the amount of investments, while the direction of these flows

\footnotetext{
${ }^{6}$ See Bloningen (2005) for a review of FDI determinants and Arauzo et al. (2010) for a review of the determinants of (national and/or foreign) industrial location.

${ }^{7}$ Data for FDI stocks and employment related to FDI are only available for the period 2007-2012. Furthermore, the FDI stock and employment data capture the static long-term influences on FDI while my purpose here is to analyze the dynamic impact of better air connections.
} 
(inward or outward) is less relevant. However, I will report below results of regressions in which the dependent variables are inward or outward FDI.

From here, we refer to the sample of countries as destination countries although, in terms of FDI flows, these countries may be destination (outward FDI) or source (inward FDI) countries. Note that my data, as is usual in studies of the determinants of FDI, do not distinguish between greenfield FDI and cross-border mergers and acquisitions.

The explanatory variable of main interest in the analysis is the total number of non-stop flights (air frequencies) between the airport of Barcelona and the airports of the destination countries. Barcelona does not operate non-stop flights with several countries in the sample so that the variable of air frequencies for many observations is 0 . In particular, the observations with zeros represent half of the entire sample.

The variable of non-stop flights should capture a reduction in travel time between Barcelona and the country of destination. In this regard, travel time can be broken down into in-vehicle time; waiting time, which is calculated as the difference between the actual and real time of departure; and, access time from the infrastructure. ${ }^{8}$ In the case of air transportation, another relevant component of the time costs is layover time, which affects flights that include a stop; the layover time includes the transfer time from one plane to another and the time waiting at the terminal for the connection.

The availability of non-stop flights should reduce in-vehicle time substantially as the itinerary is shorter than that of flights with intermediate stops and, by definition, layover time is zero on non-stop flights. Note we should add the risk associated with missing the

\footnotetext{
${ }^{8}$ Given that most trips are made in order to undertake an activity at the destination, the demand for transportation services depends not only on the monetary price of the trip but also on the travel time, since the latter implies a disutility for the transport user (Button, 2010). The sensitivity of business passengers to time is much higher than that of leisure passengers
} 
connection as an extra cost of the fastest indirect connection. Furthermore, waiting time is directly related to the service frequency. Thus, non-stop flights may reduce the waiting time and this reduction will be proportional to the flight frequencies offered.

Taking this into account, I need to address the potential simultaneous determination between air frequencies and FDI. I consider the following instrument for the air frequency variable: air frequencies from the destination country to European airports (European Union, Norway, Switzerland and Iceland). I do not include flights to Spain and hub airports in the sum of frequencies to European airports.

The variable of air frequencies to European airports should be a good instrument of air frequencies to Barcelona. Both variables are correlated because a higher demand of air services in airports of the destination country may lead to higher frequencies to both the airport of Barcelona and to the airports of the rest of Europe.

However, the demand for air services between European airports and the destination country should not be related to FDI flows from/to Barcelona, beyond its correlation with air frequencies to Barcelona. Given that the sensitivity of business passengers to time is very high, business relationships between the region of Barcelona and the destination country may be improved just by a higher number of non-stop flights between Barcelona airport and airports of such country. High-frequency air services between the destination country and other countries may only have an influence on FDI flows from/to Barcelona through better air services with an intermediate stop. However, the difference in travel time between non-stop and indirect flights may be substantial as I mention above.

Additionally, Barcelona could only take benefit from indirect flights through a small number of European hub airports where network airlines exploit the connecting traffic. In this regard, I exclude flights from the destination country to European hub airports to build my instrument. Hence, the higher connectivity from the destination country to the European 
airports that measures my instrument should not have an influence on the indirect connectivity of Barcelona.

By definition, hub airports are those airports in which a dominant network carrier exploits the transfer traffic through coordinated banks of arrivals and departures. Hence, two essential characteristics of hub airports is their large size and that they are dominated by network airlines. Network airlines in Europe are frequently the former flag carriers that are members of an international alliance (Oneworld, Star, Skyteam). Here, I consider as hub airports big European airports at which a network airline was dominant throughout the period of study. Following these criteria, I exclude these airports for the variable of air frequencies to European airports (in parenthesis it is shown the network carrier that dominates the airport): Amsterdam and Paris-Charles de Gaulle (Air France-KLM), Brussels (SN Brussels), Bucharest (TAP), Dublin (Air Lingus), Frankfurt and Munich (Lufthansa), Helsinki (Finnair), Lisbon (TAP), London-Heathrow (British Airways), Prague (Czech airlines), RomeFiumicino (Alitalia), Stockholm-Arlanda, Copenhagen and Oslo (SAS), Vienna (Austrian Airlines), Warsaw (LOT) and Zurich (Swiss). The amount of connecting flights from other European airports to Barcelona should be very small so that the exclusion of hubs may provide guarantees that the instrument is exogenous.

Note also that if the business relationships between Barcelona and some foreign country are improved, then this may increase traffic between that country and say the UK and Germany because of increased indirect flights to Barcelona with stopovers at hub airports like Heathrow or Frankfurt. However, traffic from Barcelona to large European hub airports may represent much less than 1 per cent of total flights to/from such airports and they are excluded in the computation of the air frequencies for my instrument. Hence, this potential threat to the validity of my instrument does not seem to be relevant. 
A similar instrument that I could use is air frequencies from the destination country to all airports instead of air frequencies to just European airports. I only have available data from/to non-European airports since 2005. Hence, the use of air frequencies from the destination country to all airports as instrument would require me to exclude observations for three years (from 2002 to 2004). Furthermore, the correlation between this variable and the instrumented variable is weak. This is the reason why I prefer to use flights to European airports (with the exception of Spain and hub airports). However, I will also report the results of regressions with this alternative instrument as a robustness check.

\section{Control variables}

As control factors, I use similar variables to those used in the previously cited studies about bilateral FDI flows. Table 2 shows the variables used in the empirical analysis, the descriptive statistics and the sources of information.

\section{Insert Table 2 about here}

As control variables, I include population and gross domestic product (GDP) per capita of the destination countries, and the distance between Barcelona and the largest city in the destination country. The expected sign of the population variable is positive, while the expected sign for the GDP per capita variable is also positive although this variable may reflect a range of different factors, including the endowment of skilled labor, labor costs or the quality of institutions. I also incorporate a variable for the annual GDP growth of the destination country to take into account its specific business cycle.

Distance is usually used as a proxy of trade costs. While the expected sign for this variable is clearly negative for trade, the literature on FDI finds contradictory results. Some authors find a negative relationship between FDI and distance (i.e., Stein and Daude, 2008; Wei, 2000; Wren and Jones, 2011) while others find a positive relationship (i.e., Egger and Pfaffermayr, 2004; Loungani et al., 2002). As suggested by Egger and Pfaffermayr (2004), 
distance may exert a direct impact on both trade and FDI. Hence, the impact of distance on FDI is a priori ambiguous. A positive relationship may be expected for horizontal FDI in which a firm produces abroad rather than for exports. In contrast, a negative relationship may be expected for vertical FDI in which a firm that has a geographically fragmented production process both produces and exports. Thus, the uncertain impact of distance on FDI may be due to the fact that FDI data are usually a mix of horizontal and vertical flows.

Given that the focus of the paper is to estimate the impact of the ease of information transmission on FDI flows, I add two variables that may control for this. First, I include the difference in time zones between Spain and the destination country. Following Stein and Daude (2008), air travel difficulties augment as the difference in time zones increases between the countries involved. The variable for differences in time zones may capture the transaction costs related to the need for frequent interaction in real time between the parties. Thus, I expect a negative relationship between the difference in time zones and FDI flows. Additionally, I include the number of fixed broadband Internet subscribers in the destination country. Broadband communication technology provides a means of fast, non-personal information transmission (internet, corporate intranet, videoconferencing). Additionally, the variable for broadband subscribers may also work as a proxy of economic development. Overall, I expect a positive relationship between FDI flows and broadband penetration

The variable of openness, measured as the sum of imports and exports over GDP of the destination country, controls for the effect of trade on FDI. According to Neary (2009), the expected sign for this variable is not clear a priori if we take into account that horizontal FDI and cross-border mergers represent a high proportion of total FDI. On the one hand, we would expect trade and FDI to be substitutes in horizontal FDI (except when countries are in a trading bloc) and, on the other, cross-border mergers can be expected to be encouraged by a greater degree of openness. In a similar vein, Poelhekke and Van Der Ploeg (2009) argue that 
the sign of the relationship between FDI and trade depends on whether the horizontal FDI predominates over total FDI flows.

I also include the exchange rate between the euro and the currency of the host country expressed as euros/host currency. According to the review provided by Blonigen (2005), there are contradictory theories concerning the expected sign of the relationship between the exchange rate and FDI. Thus, the expected sign of the coefficient associated with the variable is a priori ambiguous.

The role of financial markets is taken into account by including a variable for the domestic credit of the private sector over GDP. The relationship between financial markets and FDI has been analyzed in previous studies (see for example Alfaro et al., 2004) but it is not clear a priori whether domestic credit acts as a complement or substitute of FDI.

I include an index variable that is aimed to capture the level of taxation in the destination countries. Given the difficulties in obtaining complete data for a long-time span, this variable is constructed as an index variable. Higher taxes can be expected to discourage FDI flows (see for example Baccini et al., 2014 or Brulhart and Schmidheiny, 2015).

Finally, I include dummies grouping the countries by geographical area; namely North America, Latin America and the Caribbean, the Near and Middle East, the Far East, Maghreb and the former Soviet countries (with the European Economic Area serving as the geographical area of reference). In this regard, a variable that it is typically included in the analysis of the determinants of bilateral FDI flows is a dummy for common language (and/or common civil law) in order to take into consideration a factor that might reduce the transaction costs of doing business. Hence, I expect a positive sign for the coefficient of the variable for Latin American and the Caribbean, while the expected sign for the other geographical area dummies is less clear. Furthermore, the regional dummies may be capturing some specific issues as for example the economic links between Barcelona and European 
countries due to tourism. To this point, it is worth mentioning that an important proportion of short-haul traffic in Barcelona airport is due to tourism although the number of tourists coming from countries not so close like Russia is also remarkable. Finally, note that all models include unreported year dummies.

\section{ESTIMATION AND RESULTS}

I estimate the following equation using data of FDI flows between the region of Barcelona and several countries of all over the word, where the sub-index $k$ makes reference to the pair Barcelona-destination country, $c$ to the destination country and $t$ to the period:

$$
\begin{aligned}
& F D I_{k t}=\alpha+\beta_{1} \text { Air frequencies } k t+\beta_{2} \text { Population }_{c t}+\beta_{3} \text { Gross domestic product per capita }_{c t}+ \\
& +\beta_{4} \text { Distance }_{\mathrm{k}}+\beta_{5} \text { Gross domestic product }\left(\text { growth }_{c t}+\beta_{6} \text { Openess }_{c t}+\beta_{7} \text { Burden }_{\text {Tax }}+\right.
\end{aligned}
$$

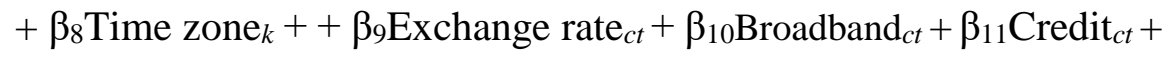

$$
\begin{aligned}
& \alpha^{\prime} \text { Geographical area }{ }_{c}+\mu^{\prime} \mathrm{D}^{\mathrm{year}}{ }_{t}+\varepsilon_{k t} \text {. }
\end{aligned}
$$

Table 2 provides the details of the variables included in this equation, as I mention above. In this section, I deal with a number of econometric issues and discuss the results of the regressions with different techniques. ${ }^{9}$ In this regard, the distribution of the dependent variable poses various econometric challenges as it can take values ranging from 0 to several millions of euros. Specifically, 12 per cent of dependent variable observations have zero values. Hence, I have to work with a zero-inflated continuous dependent variable with

\footnotetext{
${ }^{9}$ The Wooldridge test for autocorrelation in panel data shows that there is not a problem of serial autocorrelation, while the Breusch-Pagan/Cook-Weisberg test indicates a problem of heteroscedasticity. Hence, all regressions use standard errors that are robust to heteroscedasticity. I also apply the panel unit root test that can be regarded as an augmented Dickey-Fuller (ADF) test when lags are included. This test indicates that the dependent variable does not present a nonstationarity problem.
} 
extreme values so that it is severely positively skewed with a non-normal distribution. ${ }^{10}$ In the context of this research, outliers represent important information about the relationship between the variables. Indeed, observations that can be considered outliers may indicate a major investment in a particular year, which is in itself an objective of this study. Thus, I cannot exclude outliers from the regressions.

Note also that the log transformation of the dependent variable can be used to make highly skewed distributions less so. A problem that arises when using the log of FDI as a dependent variable is how to deal with the observations with zero values, since these observations may convey important information, as is the case with outliers. A potential solution is to transform the dependent variable by, for example, adding 1 to all observations. However, this is an ad-hoc approach and it forces distributional assumptions that may not be best suited to the data.

Another possible solution for a model with a continuous zero inflated dependent variable is to implement a two-step sample selection model. However, such model assumes an underlying normal distribution, which is not common in those applications when zeros represent actual responses instead of censored or missing values. Note also that the first step of the two sample selection model is doubtful in the context of this research as the non-zero values may range from close to zero to millions of Euros. Furthermore, the non-normality of the dependent variable is also found in the sub-sample that excludes observations with zeros.

Note also that the log transformation is troublesome for the explanatory variables as the variable of main interest in the analysis, the total number of non-stop flights to Barcelona, has many observations with zeros. In particular, the observations with zeros represent half of the entire sample. Thus, the use of logs in the explanatory variables would imply to miss a lot of

\footnotetext{
${ }^{10}$ The Doornik-Hansen test for multivariate normality and skewness and the kurtosis normality test for the dependent variable confirm these distributional problems.
} 
information. However, as a robustness check, I will also report results of a regression that excludes observations with zeros for the dependent variable and the variable of air frequencies. In this regression, all continuous variables are expressed in logs.

Data characterized by a nontrivial fraction of zero outcomes in the sample and a positively skewed empirical distribution of the nonzero realizations are typically found in studies of the insurance or health sectors (de Jong and Heller, 2008; Manning and Mullhay, 2001). Such distributional problems can lead to substantial bias in the OLS or Tobit regressions, especially when heteroscedasticity is also present, or to important losses in precision for other techniques.

Taking this into account, the class of regression models considered most helpful for dealing with this situation is the generalized linear model (GLM) using the gamma distribution or the Poisson pseudo-maximum likelihood estimator (PPML). ${ }^{11}$ In particular, Santos-Silva and Tenreyro (2006) analyze the suitability of different estimators for gravity (trade) equations with zero values of the dependent variable and the presence of heteroscedasticity. They show that the performance of both techniques is good when measurement errors are modest, but models with the gamma distribution perform worse when the measurement error is appreciable.

An additional advantage of both techniques is that the log transformation can be used without imposing a transformation of the dependent variable by implementing the log-link function in the case of the GLM with a gamma distribution, and estimating the model by a

\footnotetext{
${ }^{11}$ Note that PPML does not require the data to follow a Poisson distribution so that it can be used when the dependent variable is a continuous variable (Gourieroux et al., 1984).
} 
multiplicative form in the case of the PPML estimator. Hence, my preferred estimation technique is the PPML model. ${ }^{12}$

Taking all this into account, I report the results using different techniques as a robustness check; namely, Ordinary Least Squares (OLS), Two-Stage Least Squares (2SLS), PPML, Generalized Linear Model (GLM) with a gamma distribution and GLM with a negative binomial distribution. Note that I have a panel with observations for countries repeated several years. In the OLS, 2SLS and PPML regressions, I apply clusters at the country level to take into account the correlation between observations for a given country. The GLM regressions are executed directly in a panel data approach by estimating a populationaveraged panel data model.

Table 3 shows the results of the estimates applying the different techniques described above. In all regressions, the variable of air frequencies is positive and statistically significant. The computed elasticities at sample means differ depending on the estimation technique used. If we examine the elasticities obtained in the regressions using PPML and the gamma distribution, a 1 per cent increase in the number of air frequencies leads to about a 0.15 per cent increase in FDI flows. Such elasticity is about 0.4 in the regression that uses OLS and 2SLS, and it is about 0.25 in the regression that uses the negative binomial distribution.

\section{Insert Table 3 about here}

\footnotetext{
${ }^{12}$ I use the ivpoisson command of Stata software to handle the endogeneity of the air frequencies variable in the context of PPML. Here, two alternative instrumental variables strategies are available; the control function approach and the Generalized Method of Moments (GMM) approach. The GMM provides the general framework for standard Instrumental Variables estimation where the fitted values in the first stage are used in the second stage, while the control function estimator uses fitted residuals rather than fitted values in the second stage (see Wooldridge, 2010 for mathematical details about these two methods). Regressions are run with the GMM procedure because it reports similar but more stable elasticities than the control function approach.
} 
While I apply an instrumental variables procedure for air frequencies in all regressions reported in table 3, only the standard 2SLS regression reports results of suitability of the instrument (frequencies from the destination country to European airports except Spain and hub airports). The instrument is strong, as is shown in the results of the under-identification test and the partial $\mathrm{R}^{2}$ of the first regression. I cannot apply the Sargan test of overidentifying restrictions because this test needs more than one instrument.

Results for the control variables are similar regardless the econometric technique used. As expected in gravity equations, the variables of population and GDP per capita are positive and statistically significant in all regressions. Furthermore, the variable of distance is negative and statistically significant.

The dummy variable for Latin American and Caribbean countries is positive and statistically significant in all regressions and the magnitude of its coefficient is much higher than that of the dummies for other geographical areas. With the exception of Brazil, all countries in this geographical area share a common language with the urban area of Barcelona. Furthermore, the variable of broadband penetration is positive and statistically significant in all regressions except that using GLM with a gamma distribution in which it is positive but not significant. Finally, the variable of difference in time zones is negative and statistically significant in all regressions except that using PPML.

As for the other control factors, domestic credit seems to act as a complement of FDI although such result does not hold when I use PPML. Furthermore, higher taxes discourage FDI flows. Furthermore, it is not clear the impact of a greater degree of openness on FDI as the statistical significance and even the sign changes depending on the estimation technique used. A possible explanation is that FDI may be driven by different purposes including horizontal or vertical FDI, and greenfield investments or cross-border mergers and 
acquisitions. Hence, FDI flows from/to Barcelona may represent a mix of all these different purposes.

Overall, the relevant impact of the air frequencies variable confirms that the ease of information transmission is a major determinant of the amount of bilateral FDI flows. Results for the dummy variable for Latin American and Caribbean countries and for the variable of broadband penetration may be similarly interpreted.

\section{ROBUSTNESS CHECKS}

In this section, I perform several robustness checks to results of previous regressions (which are my baseline regressions) reported in table 3. I only report results using the PPML model which is a frequently used technique in gravity equations. The non-normality of the dependent variable may cast some doubts on the consistency of 2SLS regressions. Furthermore, recall that Santos-Silva and Tenreyro (2006) show that models with the gamma distribution may perform worse than PPML when the measurement error is appreciable which may be the case in regressions with several countries. Finally, the negative binomial model is used more frequently for count data

Table 4 shows the results of the estimates using different instruments for air frequencies. It is also shown the first-stage results of the instrumental variables procedure. The aim of these regressions is to examine the sensitiveness of results for the air frequency variable to the use of different instruments. Hence, for the sake of simplicity, I only report results for the air frequencies variable.

\section{Insert Table 4 about here}

In the first and third regressions, I do not apply an instrumental variables procedure. The second and fourth regressions use the same instrument as in the previous regressions. The third and fourth regressions use data for the period 2005-2015 to be more comparable with the regressions using other instruments. Indeed, the fifth regression uses as instruments air 
frequencies to all airports (except Spanish airports). Recall that the number of observations for the latter regression is smaller as data are only available since 2005. The last regression uses three lags of air frequencies as instruments. The use of lags of the endogenous explanatory variable is a typical way to deal with the simultaneous determination problem. I choose three lags to mitigate the standard problem with this solution which is the strong correlation between the contemporaneous variable and its lags.

Regarding the results of the first-stage regression, the coefficient of all instruments used is positive and statistically significant. In all regressions, the variable of air frequencies is positive and statistically significant. The value of the elasticity for the air frequency variable is about 0.19 when I do not apply an instrumental variables procedure. The use of air frequencies to European airports (except Spain and hub airports) leads to lower elasticities. Similarly, the use of air frequencies to all airports seems to reduce the magnitude of the elasticity although it is still statistically significant. The estimated elasticity when I use lags of the endogenous explanatory variable is similar to that obtained when I do not apply an instrumental variables procedure. Overall, I could infer from these results that the elasticity of FDI to air frequencies is slightly lower after controlling for the endogeneity.

Table 5 shows the results of the estimates of two different regressions that use inward and outward FDI as dependent variable, respectively. While the variable of air frequencies is positive and statistically significant in both regressions, the obtained elasticity is higher in the regression that uses inward FDI as dependent variable. Hence, better air connections between the region of Barcelona and the destination country seem to have benefits in terms of higher investments for the two endpoints although the effect is stronger for Barcelona as investment recipient.

\section{Insert Table 5 about here}


Results for the control variables are similar as those reported in table 3. Interestingly, the variable of broadband penetration is positive and statistically significant in both regressions. Furthermore, the burden tax variable is negative and significant for both inward and outward FDI. While the negative sign of the coefficient of the tax variable is not surprising for inward FDI, less clear is the interpretation of this result for outward FDI.

It is also remarkable that the coefficient on openness is positive and statistically significant with inward FDI suggesting that there are complementarities between trade and inward FDI. Given that vertical FDI or cross-border mergers can be expected to be encouraged by a greater degree of openness, such result suggests a stronger role of these types of investments in inward FDI.

Table 6 shows the results of the estimates with different control variables. In the first regression, I only consider as control variables the essential variables of gravity models; population, GDP per capita and distance. In the second regression, I add the dummies for the different geographical areas considered in the analysis. In the third regression, I consider all control variables except the dummies for the different geographical areas. In the fourth regression, I use three lags of the GDP per capita variable instead of current values to check the influence on the results of the potential endogeneity problem of this control variable as FDI flows may have an impact on GDP per capita. ${ }^{13}$ In the fifth regression, I use as an additional explanatory variable the interaction between the variables of broadband penetration and air frequencies to examine the differential impact of air frequencies given a higher broadband penetration.

\section{Insert Table 6 about here}

\footnotetext{
${ }^{13}$ To this regard, the explanatory variable refers to the GDP of the destination country and the potential endogeneity problem should be more worrisome for the GDP of the region of origin.
} 
The omission of some relevant control variables could distort the identification of the effect of air frequencies on FDI flows. In this regard, results of the two first regressions reported in table 6 provide elasticities slightly higher than in previous regressions, while the elasticity reported in the third regression is slightly lower. In any case, the use of different control factors confirms the variable of air frequencies has a positive and statistically significant impact on the magnitude of FDI investments.

The use of three lags of the GDP per capita variable instead of current values does not alter the results for the main variable of interest (air frequencies), and for the GDP per capita variable. Interestingly, the interaction variable (broadband $\mathrm{x}$ Air frequencies) is negative but not statistically significant. Hence, the substitution effect between broadband and air services seems to be modest.

Table 7 shows the results of the estimates with three different sub-samples. In the first regression, I exclude observations with zeros in the variables of FDI and air frequencies. All continuous variables in this regression are expressed in logs. In the second regression, I exclude the countries that are members of the European Union. The policy implications of the results for this sub-sample may be particularly interesting. While the EU airline market has been working since 1997 as a domestic market, air traffic relations between EU and other countries are frequently regulated by bilateral agreements. In the third regression, I exclude countries that have non-stop flights to Barcelona through several cities like the United States, Germany, France, United Kingdom, Russia and countries in the North of Africa. An obvious limitation of my data is that are at the country level for one of the endpoints. Hence, this subsample may dilute such limitation as non-stop flights from Barcelona in this restricted sample have as their destination only the largest city (as much) in the country considered.

\section{Insert Table 7 about here}


Again, the variable of air frequencies is positive and statistically significant in the three regressions. In the sample that focuses on observations with positive values in the FDI and air frequencies variables, the elasticity of the air frequencies variable is slightly higher than in previous regressions although the control variables seem to work worse.

In the sample for non-EU countries, the computed elasticity is higher than that obtained in the regressions that use the whole sample. In particular, a 1 per cent increase in the number of air frequencies leads to about a 0.6 per cent increase in FDI flows. In the restricted sample that excludes countries with several cities connected by air to Barcelona, the elasticity of the air frequencies variable is lower (but still statistically significant) than that obtained in the previous regressions.

Finally, Table 8 shows the results of the estimates with a dataset that adds Madrid as the region of reference. In the first regression, I focus on the region of Madrid. In the second regression, I show the results with both regions (Barcelona and Madrid) as reference regions. In the third regression, results with the regions of Barcelona and Madrid are considered including destination country fixed effects. If I use country fixed effects instead of regional dummies with one region of reference (either Barcelona or Madrid), the PPML model with an endogenous explanatory variable does not converge to any value. It could be the case that the sample is too small to handle 81 country fixed effects. However, the regression that includes observations for Barcelona and Madrid uses a sample that doubles the number of observations with the same fixed effects. In this latter regression, the model converges even with the inclusion of country fixed effects.

Again, the variable of air frequencies is positive and statistically significant and the elasticities are higher to those obtained in previous regressions. Given that Madrid and Barcelona concentrate most of FDI from/to Spain and most of international travel for business purposes, results of my analysis can be generalized not just to Barcelona but to the whole 
country. Note also that the heterogeneity in the regions of reference (being Madrid the political capital of the country and its airport a hub of a network carrier) does not seem to alter the main result of this paper; the existence of a strong relationship between air frequencies and FDI.

\section{CONCLUSIONS}

In this paper, I find evidence that the reduction in travel time due to the availability of nonstop flights, scheduled with sufficient frequency, increases the amount of FDI because of the enhanced transmission of information. Such result is robust to the use of different techniques, instruments and control factors, to the direction of the investments, and to the use of different samples of destination countries and origin regions. Given that FDI may contribute to growth through different channels (technological spillovers, access to foreign markets, more financial resources), the results of this study provide new evidence in favor of a relevant economic impact of air services.

While results of my analysis suggest a clear link between FDI flows and international air services, a project for future research could be to examine such link for a sample with several origin and destination regions.

My results suggest the existence of positive externalities associated with the expansion of airport capacities. However, having said that, the aim here is not to provide a comprehensive welfare analysis of airport capacity expansions. Furthermore, an implication of this paper is that the innovations associated with electronic communications do not appear to eliminate the role of transportation in facilitating face-to-face contacts.

Finally, the results need to be seen in the broader context of the current debate concerning the lifting of regulatory restrictions in the airline market. These markets in Europe and the U.S. have been affected in recent years by the increasing presence of foreign airlines. While this is seen as being a motive of concern for managers of European and U.S. network airlines, 
this paper shows that the increasing presence of foreign airlines can bring new business opportunities for regions due to improved connections with the rest of the world. 


\section{References}

Albalate, Daniel and Xavier Fageda. 2016. "High-tech employment and transportation: Evidence from the European regions," Regional Studies, 50 (9), 1564-1578.

Alfaro, Laura, Areendam Chanda, Sebnem Kalemli-Ozcan and Selin Sayek. 2004. "FDI and economic growth: the role of local financial markets," Journal of International Economics, 64 (1), 89-112.

Arauzo-Carod, Josep-Maria, Daniel Liviano-Solis and Miguel Manjón-Antolin. 2010. "Empirical studies in industrial location: an assessment of their methods and results," Journal of Regional Science, 50 (3), 685-711.

Leonardo Baccini, Quan Li and Irina Mirkina. 2014. "Corporate tax cuts and foreign direct investment," Journal of Policy Analysis and Management, 33 (4), 977-1006.

Baltabaev, Botirjan. 2014. "Foreign direct investment and total factor productivity growth: New macro-evidence," The World Economy, 37 (2), 331-334.

Borensztein, Eduardo, José D. Gregorio and Jong-Wha Lee. 1998. "How does foreign direct investment affect economic growth?," Journal of International Economics, 45 (1), 115135.

Brainard, S.Lael. 1997. “An empirical assessment of the proximity-concentration trade-off between multinational sales and trade," American Economic Review, 87 (4), 520-544.

Brülhart, Marius and Kurt Schmidheiny. 2015. "Estimating the rivalness of State-level inward FDI, Journal of Regional Science," 55 (1), 139-148.

Bel, Germà and Xavier Fageda. 2008. "Getting there fast, Globalization, intercontinental flights and location of headquarters," Journal of Economic Geography, 8 (4), 471-495.

Bilotkach, Volodymyr. 2015. “Are Airports Engines of Economic Development? A Dynamic Panel Data Approach," Urban Studies 52 (9), 1577-1593. 
Blonigen, Bruce. 2005. “A Review of the Empirical Literature on FDI Determinants, Atlantic Economic Journal," 33 (4), 383-403.

Blyde, Juan and Danielken Molina. 2015. "Logistic infrastructure and the international location of fragmented production," Journal of International Economics, 95 (2), 319-332.

Brueckner, Jan. 2003. "Airline traffic and urban economic development," Urban Studies, 40 (8), 1455-1469.

Button, Kenneth. 2010. Transport Economics, $3^{\text {rd }}$ edition. Cheltenham, UK: Edward Elgar.

Daniel, Joseph P. and Marc von der Ruhr. 2014. Transportation costs and US manufacturing FDI, Review of International Economics, 22 (2), 299-309.

Duranton, Gilles and Matthew Turner. 2012. Urban growth and transportation, Review of Economic Studies, 79 (4), 1407-1440.

Egger, Peter and Michael Pfaffermayr. 2004. "Distance, Trade and FDI: A Hausman-Taylor SUR Approach,” Journal of Applied Econometrics, 19 (2), 2553-64.

Ford, Timothy, Jonathan C. Rork and Bruce T. Elmslie. 2008. "Considering the source: Does the country of origin of FDI matter to economic growth?," Journal of Regional Science, 48 (2), 329-357.

Gaspar, Jess and Edward Glaeser. 1998. "Information technology and the future of cities," Journal of Urban Economics, 43 (1), 136-156

Giroud, Xavier. 2013. "Proximity and investment: Evidence from plant-level data, Quarterly Journal of Economics," 128, 861-915.

Gourieroux, Christian, Alain Monfort and Alain Trognon. 1984. "Pseudo Maximum Likelihood Methods: Applications to Poisson Models," Econometrica, 52 (3), 701-720.

Green, Richard K. 2007. "Airports and Economic Development," Real Estate Economics, 35 (1), 91-112. 
Hovhannisyan, Nune and Wolfgang Keller. 2015. International business travel: an engine of innovation?, Journal of Economic Growth, 20 (1), 75-104.

Iamsiraroj, Sasi. 2016. "The foreign direct investment-economic growth nexus," International Review of Economics and Finance, 42, 116-133

de Jong, Piet and Gillian Heller. 2008. Generalized Linear Models for Insurance Data. Cambridge, UK: Cambridge University Press

Leichenko, Robin and Rodney Erickson. 1997. "Foreign Direct Investment and State Export Performance," Journal of Regional Science, 37 (2), 307-329.

Loungani, Prakash, Ashoka Mody and Assaf Razin. 2002. "The global disconnect: the role of transactional distance and scale economies in gravity equations," Scottish Journal of Political Economy, 49 (5), 526-543.

Manning, Willard and John Mullahy. 2001. "Estimating Log Models: To Transform or Not to Transform?," Journal of Health Economics, 20 (4), 461-494.

Neary, J.Peter. 2009. "Trade costs and foreign direct investment," International Review of Economics and Finance," 18 (2), 207-218.

Newman, Carol, John Rand, Theodore Talbot and Finn Tarp. 2015. Technology transfers, foreign investment and productivity spillovers, European Economic Review, 76, 168-187.

Percoco, Marco. 2010. "Airport Activity and Local Development, Evidence from Italy," Urban Studies, 47 (11), 2427, 2443.

Poelhekke, Steven and Frederik Van Der Ploeg. 2009. "Foreign direct investment and urban concentrations: unbundling spatial lags," Journal of Regional Science, 49 (4), 749-775.

Santos-Silva, Joao and Silvana Tenreyro. 2006. "The log of gravity, The Review of Economics and Statistics, ” 88 (4), 641-658.

Sheard, Nicholas. 2014. "Airports and urban sectoral employment," Journal of Urban Economics, 80, 133-152. 
Stein, Ernesto and Chistian Daude. 2008. "Longitude matters: Time zones and the location of foreign direct investment," Journal of International Economics, 71 (1), 96-112.

Storper, Michael and Anthony Venables. 2004. "Buzz: face-to-face contact and the urban economy," Journal of Economic Geography, 4 (4), 351-370.

Wang, Jian and Xiao Wang. 2015. "Benefits of foreign ownership: Evidence from foreign direct investment in China," Journal of International Economics, 97 (2), 325-338.

Wei, Shang-Jin. 2000. "How taxing is corruption on international investors?", Review of Economics and Statistics, 82 (1), 1-11.

Wooldridge, Jeffrey. 2010. Econometric Analysis of Cross Section and Panel Data, 2nd edition. Cambridge, U.S.: MIT Press.

Wren, Colin and Jonathan Jones. 2011. “Assessing the regional impact of grants on FDI location: Evidence from U.K regional policy, 1985-2005," Journal of Regional Science, 51 (3), 497-517. 


\section{TABLES}

TABLE 1. List of countries included in the analysis

\begin{tabular}{|c|c|}
\hline $\begin{array}{l}\text { European Economic Area: } \\
\text { Bustria, } \\
\text { Belgium, Bulgaria, Croatia, Cyprus, } \\
\text { Czech Republic, Denmark, Estonia, } \\
\text { France, Finland, Germany, Greece, } \\
\text { Hungary, Ireland, Italy, Latvia, Lithuania. } \\
\text { Luxembourg, Malta, Netherlands, } \\
\text { Norway, Poland, Portugal, Romania, } \\
\text { Slovakia, Slovenia, Spain, Sweden, } \\
\text { Switzerland, United Kingdom }\end{array}$ & $\begin{array}{l}\text { Near and Middle East: Egypt, India, } \\
\text { Israel, Jordan, Lebanon, Pakistan, Qatar, } \\
\text { Saudi Arabia, Turkey, United Arab } \\
\text { Emirates }\end{array}$ \\
\hline North America: Canada, United States & $\begin{array}{l}\text { Far East: China, Hong Kong, Indonesia, } \\
\text { Japan, Malaysia, Philippines, Singapore, } \\
\text { South Korea, Taiwan, Thailand. }\end{array}$ \\
\hline $\begin{array}{l}\text { Latin American and Caribbean } \\
\text { countries: Argentina, Belize, Brazil, } \\
\text { Bolivia, Chile, Colombia, Costa Rica, } \\
\text { Cuba, Dominican Republic, Ecuador, } \\
\text { Guatemala, Honduras, Mexico, Panama, } \\
\text { Paraguay, Peru, El Salvador, Uruguay, } \\
\text { Venezuela }\end{array}$ & $\begin{array}{l}\text { Maghreb: Algeria, Morocco, Mauritania, } \\
\text { Tunis }\end{array}$ \\
\hline $\begin{array}{l}\text { Post-Soviet States: Armenia, Belarus, } \\
\text { Georgia, Kazajastan, Russia, Ukraine, } \\
\text { Uzbekistan }\end{array}$ & \\
\hline
\end{tabular}


TABLE 2. Descriptive statistics of the variables used in the empirical analysis

\begin{tabular}{|c|c|c|c|c|c|c|}
\hline Variable & Description & Source & Mean & $\begin{array}{l}\text { Standard } \\
\text { Deviation }\end{array}$ & $\begin{array}{l}\text { Minimum } \\
\text { Value }\end{array}$ & $\begin{array}{c}\text { Maximum } \\
\text { value }\end{array}$ \\
\hline Total FDI & $\begin{array}{c}\text { Gross foreign direct } \\
\text { investment (thousands of } \\
\text { euros) }\end{array}$ & $\begin{array}{l}\text { Spanish Ministry of } \\
\text { Economics and } \\
\text { competitiveness }\end{array}$ & 80571.44 & 243352.1 & 0 & 2652578 \\
\hline Air frequencies & $\begin{array}{l}\text { Number of annual flights } \\
\text { between Barcelona airport } \\
\text { and the destination country }\end{array}$ & RDC aviation /AENA & 972.14 & 2488.08 & 0 & 13820 \\
\hline $\begin{array}{l}\text { Air frequencies } \\
\text { (instrument) }\end{array}$ & $\begin{array}{l}\text { Number of annual flights } \\
\text { between European airports } \\
\text { (excluding Spain and hub } \\
\text { airports) and the destination } \\
\text { country }\end{array}$ & RDC aviation & 39364.68 & 102110.5 & 0 & 681323 \\
\hline Population & $\begin{array}{l}\text { Number of inhabitants of the } \\
\text { destination country } \\
\text { (millions) }\end{array}$ & World Bank & 66.85 & 199.33 & 0.26 & 1364.27 \\
\hline $\begin{array}{c}\text { Gross domestic } \\
\text { product per capita } \\
(\text { level })\end{array}$ & $\begin{array}{l}\text { Gross national income per } \\
\text { capita (current US dollars) }\end{array}$ & World Bank & 18129.44 & 20062.2 & 420 & 104010 \\
\hline $\begin{array}{l}\text { Gross domestic } \\
\text { product (growth) }\end{array}$ & $\begin{array}{l}\text { GDP growth (annual } \\
\text { percentage) }\end{array}$ & World Bank & 3.70 & 3.94 & -14.81 & 26.17 \\
\hline Distance & $\begin{array}{l}\text { Number of kilometres } \\
\text { between Barcelona airport } \\
\text { and main airport in the } \\
\text { destination country }\end{array}$ & Webflyer.com & 5028.06 & 3631.68 & 520 & 11700 \\
\hline Openess & $\begin{array}{l}\text { Percentage of imports and } \\
\text { exports over GDP }\end{array}$ & World Bank & 97.27 & 66.39 & 21.16 & 458.33 \\
\hline Burden tax & $\begin{array}{c}\text { Index variable based on tax } \\
\text { revenue over GDP: } 1 \text { if tax } \\
\text { revenue }<10,2 \text { if tax revenue } \\
\text { between } 11-15,3 \text { if tax } \\
\text { revenue }>15\end{array}$ & World Bank & 2.38 & 0.66 & 1 & 3 \\
\hline Time_zone & $\begin{array}{c}\text { Standard Time zone } \\
\text { difference with Spain }\end{array}$ & $\begin{array}{c}\text { Web site: } \\
\text { 24Timezones.com }\end{array}$ & 2.92 & 2.68 & 0 & 8 \\
\hline Credit & $\begin{array}{l}\text { Domestic credit to the } \\
\text { private sector over GDP }\end{array}$ & World Bank & 69.30 & 51.10 & 1.12 & 311.98 \\
\hline Exchange rate & Euros per local currency & $\begin{array}{l}\text { International Monetary } \\
\text { Fund (International } \\
\text { Financial Statistics) \& } \\
\text { web site: } \\
\text { http://www.xe.com/ }\end{array}$ & 0.43 & 0.44 & 0.000053 & 1.99 \\
\hline Broadband & $\begin{array}{c}\text { Fixed broadband Internet } \\
\text { subscribers (per } 100 \text { people) }\end{array}$ & World Bank & 11.48 & 11.78 & 0 & 42.56 \\
\hline
\end{tabular}


TABLE 3. Results of the estimates - different techniques

\begin{tabular}{|c|c|c|c|c|c|}
\hline Dependent variable & $\log ($ FDI + 1) & $\log ($ FDI + 1) & FDI & FDI & FDI \\
\hline Method & OLS & 2SLS & PPML & $\begin{array}{l}\text { GLM with a } \\
\text { gamma } \\
\text { distribution }\end{array}$ & $\begin{array}{l}\text { GLM with a } \\
\text { negative } \\
\text { binomial }\end{array}$ \\
\hline Air frequencies & $\begin{array}{c}0.00047 \\
(0.000003)^{* * *}\end{array}$ & $\begin{array}{c}0.00040 \\
(0.00003)^{* * *}\end{array}$ & $\begin{array}{c}0.00016 \\
(0.00003)^{* * *}\end{array}$ & $\begin{array}{c}0.00017 \\
(0.00009)^{* *}\end{array}$ & $\begin{array}{c}0.00024 \\
(0.00002)^{* * *}\end{array}$ \\
\hline $\begin{array}{c}\text { Elasticity of FDI to air } \\
\text { frequencies }\end{array}$ & $\begin{array}{c}0.46 \\
(0.02)^{* * *}\end{array}$ & $\begin{array}{c}0.39 \\
(0.03)^{* * *}\end{array}$ & $\begin{array}{c}0.16 \\
(0.03) * * *\end{array}$ & $\begin{array}{c}0.17 \\
(0.09)^{* *}\end{array}$ & $\begin{array}{c}0.24 \\
(0.02)^{* * *}\end{array}$ \\
\hline \multicolumn{6}{|l|}{ Controls } \\
\hline Population & $\begin{array}{c}0.005 \\
(0.0003)^{* * *}\end{array}$ & $\begin{array}{c}0.0053 \\
(0.0004)^{* * *}\end{array}$ & $\begin{array}{c}0.003 \\
(0.0003)^{* * *}\end{array}$ & $\begin{array}{c}0.003 \\
(0.0005)^{* * *}\end{array}$ & $\begin{array}{c}0.003 \\
(0.0002)^{* * *}\end{array}$ \\
\hline $\begin{array}{l}\text { Gross domestic product } \\
\text { per capita }\end{array}$ & $\begin{array}{c}0.000039 \\
(7.90 \mathrm{e}-06)^{* * *}\end{array}$ & $\begin{array}{c}0.00004 \\
(7.79 \mathrm{e}-06)^{* * *}\end{array}$ & $\begin{array}{c}0.000025 \\
(6.24 \mathrm{e}-06)^{* * *}\end{array}$ & $\begin{array}{c}0.00005 \\
(0.00001)^{* * *}\end{array}$ & $\begin{array}{c}0.00004 \\
(3.82 \mathrm{e}-06)^{* * *}\end{array}$ \\
\hline Distance & $\begin{array}{c}-0.0001 \\
(0.0008)^{* * *}\end{array}$ & $\begin{array}{c}-0.0002 \\
(0.00008) * * *\end{array}$ & $\begin{array}{c}-0.0003 \\
(0.00011)^{* * *}\end{array}$ & $\begin{array}{c}-0.0005 \\
(0.0002)^{* *}\end{array}$ & $\begin{array}{c}-0.0002 \\
(0.00005)^{* * *}\end{array}$ \\
\hline $\begin{array}{l}\text { Gross domestic product } \\
\text { (growth) }\end{array}$ & $\begin{array}{c}-0.09 \\
(0.02)^{* * *}\end{array}$ & $\begin{array}{c}-0.09 \\
(0.02)^{* * *}\end{array}$ & $\begin{array}{c}-0.06 \\
(0.02)^{* *}\end{array}$ & $\begin{array}{r}-0.001 \\
(0.03)\end{array}$ & $\begin{array}{c}0.01 \\
(0.01)\end{array}$ \\
\hline Openess & $\begin{array}{c}0.002 \\
(0.001)^{*}\end{array}$ & $\begin{array}{l}0.0016 \\
(0.014)\end{array}$ & $\begin{array}{c}0.003 \\
(0.001)^{* *}\end{array}$ & $\begin{array}{l}-0.0009 \\
(0.009)\end{array}$ & $\begin{array}{c}0.003 \\
(0.009)^{* * *}\end{array}$ \\
\hline Burden Tax & $\begin{array}{c}-0.33 \\
(0.15)^{* *}\end{array}$ & $\begin{array}{c}-0.35 \\
(0.15)^{* * *}\end{array}$ & $\begin{array}{c}-0.31 \\
(0.14)^{* *}\end{array}$ & $\begin{array}{l}-0.39 \\
(0.39)\end{array}$ & $\begin{array}{c}-0.77 \\
(0.09) * * *\end{array}$ \\
\hline Time zone & $\begin{array}{c}-0.59 \\
(0.09)^{* * *}\end{array}$ & $\begin{array}{c}-0.59 \\
(0.09)^{* * *}\end{array}$ & $\begin{array}{c}0.08 \\
(0.14) \\
\end{array}$ & $\begin{array}{c}-0.27 \\
(0.26)^{* * *} \\
\end{array}$ & $\begin{array}{c}-0.38 \\
(0.06)^{* * *}\end{array}$ \\
\hline Exchange rate & $\begin{array}{l}-0.18 \\
(0.25)\end{array}$ & $\begin{array}{l}-0.05 \\
(0.26)\end{array}$ & $\begin{array}{c}0.46 \\
(0.22)^{* *}\end{array}$ & $\begin{array}{l}0.05 \\
(0.5) \\
\end{array}$ & $\begin{array}{l}-0.22 \\
(0.15)\end{array}$ \\
\hline Broadband & $\begin{array}{c}0.04 \\
(0.01)^{* * *}\end{array}$ & $\begin{array}{c}0.04 \\
(0.01)^{* * *}\end{array}$ & $\begin{array}{c}0.02 \\
(0.01)^{*}\end{array}$ & $\begin{array}{l}0.008 \\
(0.02)\end{array}$ & $\begin{array}{c}0.04 \\
(0.006)^{* * *}\end{array}$ \\
\hline Credit & $\begin{array}{c}0.01 \\
(0.002)^{* * *}\end{array}$ & $\begin{array}{c}0.01 \\
(0.002)^{* * *}\end{array}$ & $\begin{array}{r}-0.0008 \\
(0.001) \\
\end{array}$ & $\begin{array}{c}0.009 \\
(0.005) *\end{array}$ & $\begin{array}{c}0.01 \\
(0.001)^{* * *}\end{array}$ \\
\hline $\mathrm{D}^{\text {North_America }}$ & $\begin{array}{c}4.30 \\
(0.61)^{* * *}\end{array}$ & $\begin{array}{c}4.15 \\
(0.61)^{* * *}\end{array}$ & $\begin{array}{c}1.85 \\
(0.81)^{* *}\end{array}$ & $\begin{array}{c}2.57 \\
(1.40)^{*}\end{array}$ & $\begin{array}{c}1.72 \\
(0.44)^{* * *}\end{array}$ \\
\hline $\begin{array}{l}\mathrm{D}^{\text {Latin American \& Caribbean }} \\
\text { countries }\end{array}$ & $\begin{array}{c}6.87 \\
(0.83) * * *\end{array}$ & $\begin{array}{c}6.96 \\
(0.63) * * * \\
\end{array}$ & $\begin{array}{c}3.08 \\
(0.92)^{* * *} \\
\end{array}$ & $\begin{array}{c}6.18 \\
(1.48)^{* * *} \\
\end{array}$ & $\begin{array}{c}5.33 \\
(0.39)^{* * *} \\
\end{array}$ \\
\hline $\mathrm{D}^{\text {Near \& Middle East }}$ & $\begin{array}{c}0.83 \\
(0.40)^{* *}\end{array}$ & $\begin{array}{c}0.82 \\
(0.39)^{* *}\end{array}$ & $\begin{array}{l}-0.18 \\
(0.54)\end{array}$ & $\begin{array}{c}0.84 \\
(0.61)\end{array}$ & $\begin{array}{c}0.62 \\
(0.21)^{* * *}\end{array}$ \\
\hline $\mathrm{D}^{\text {Far east }}$ & $\begin{array}{c}3.62 \\
(0.77)^{* *}\end{array}$ & $\begin{array}{c}3.77 \\
(0.76)^{* * *}\end{array}$ & $\begin{array}{c}0.31 \\
(1.14)\end{array}$ & $\begin{array}{c}3.35 \\
(1.91)^{*}\end{array}$ & $\begin{array}{c}1.60 \\
(0.48)^{* * *}\end{array}$ \\
\hline $\mathrm{D}^{\text {Post-soviet_states }}$ & $\begin{array}{c}0.24 \\
(0.38)\end{array}$ & $\begin{array}{c}0.28 \\
(0.38)\end{array}$ & $\begin{array}{l}-0.14 \\
(0.46)\end{array}$ & $\begin{array}{l}-0.59 \\
(0.84)\end{array}$ & $\begin{array}{l}-0.33 \\
(0.23)\end{array}$ \\
\hline $\mathrm{D}^{\text {Maghreb }}$ & $\begin{array}{c}1.55 \\
(0.49)^{* * *}\end{array}$ & $\begin{array}{c}1.68 \\
(0.49)^{* * *}\end{array}$ & $\begin{array}{c}0.16 \\
(0.59)\end{array}$ & $\begin{array}{c}0.45 \\
(0.74)\end{array}$ & $\begin{array}{c}1.15 \\
(0.27)^{* * *}\end{array}$ \\
\hline Intercept & $5.37(0.68)^{* * *}$ & $5.65(0.67)^{* * *}$ & $8.54(0.69)^{* * *}$ & $10.27(2.07)^{* * *}$ & $9.80(0.36)^{* * *}$ \\
\hline Year fixed effects & YES & YES & YES & YES & YES \\
\hline $\begin{array}{l}\text { Joint significance test } \\
R^{2} \\
\text { Number observations }\end{array}$ & $\begin{array}{c}77.15 * * * \\
0.50 \\
1134\end{array}$ & $\begin{array}{c}79.53 * * * \\
0.51 \\
1134\end{array}$ & $\begin{array}{c}- \\
0.46 \\
1134\end{array}$ & $\begin{array}{c}1034.34 * * * \\
- \\
1134\end{array}$ & $\begin{array}{c}2131.97 * * * \\
- \\
1134\end{array}$ \\
\hline
\end{tabular}

Notes: a) Standard errors in parenthesis. They are robust to heteroscedasticity in all regressions, and clustered at the country level in the OLS, 2SLS and PPML regressions. In the GLM regressions, I impose an exchangeable within country correlation structure. b) Statistical significance at 1 percent $(* * *), 5$ percent $(* *), 10$ percent $(*)$. c) Instrument of air frequencies is air frequencies to European airports (except Spain and hub airports). Stata only report tests for the suitability of instruments in the 2SLS regressions. In this regression, the partial $\mathrm{R}^{2}$ of the instrument is 0.69 , and the underidentification test (Kleibergen-Paap test) takes a value of 79.53 being statistically significant at the 1 percent level. 
TABLE 4. Results of the estimates (PPML)- Different instruments

\begin{tabular}{|c|c|c|c|c|c|c|}
\hline $\begin{array}{l}\text { Instruments for air } \\
\text { frequencies }\end{array}$ & $\begin{array}{c}\text { None. } \\
\text { Period: } 2002-2015\end{array}$ & $\begin{array}{l}\text { Air frequencies to } \\
\text { European airports. }^{\text {a }} \\
\text { Period: 2002-2015 }\end{array}$ & $\begin{array}{c}\text { None. } \\
\text { Period: } 2005-2015\end{array}$ & $\begin{array}{l}\text { Air frequencies to } \\
\text { European airports. } \\
\text { Period: } 2005-2015\end{array}$ & $\begin{array}{l}\text { Air frequencies to } \\
\text { all airports. } \\
\text { Period: } 2005-2015\end{array}$ & $\begin{array}{c}\text { Lagged frequencies } \\
\text { (three years). } \\
\text { Period: } 2005-2015\end{array}$ \\
\hline & & \multicolumn{4}{|c|}{$\begin{array}{l}\text { FIRST-STAGE RESULTS. Dependent variable: Air frequencies } \\
\end{array}$} & \\
\hline $\begin{array}{l}\text { Air frequencies to EU } \\
\text { airports }\end{array}$ & - & $\begin{array}{c}0.02 \\
(0.0008)^{* * * *}\end{array}$ & - & $\begin{array}{c}0.02 \\
(0.001)^{* * *}\end{array}$ & - & - \\
\hline $\begin{array}{l}\text { Air frequencies to all } \\
\text { airports }\end{array}$ & - & - & - & - & $\begin{array}{c}0.00039 \\
(0.00007)^{* * *}\end{array}$ & - \\
\hline \multirow[t]{2}{*}{$\begin{array}{c}\text { Lagged frequencies } \\
\text { (three years) }\end{array}$} & - & - & - & - & - & $\begin{array}{c}0.99 \\
(0.02)^{* * *}\end{array}$ \\
\hline & & \multicolumn{4}{|c|}{ SECOND-STAGE RESULTS. Dependent variable: FDI } & \\
\hline Air frequencies & $\begin{array}{c}0.00019 \\
(0.00002)^{* * *}\end{array}$ & $\begin{array}{c}0.00016 \\
(0.00003)^{* * *}\end{array}$ & $\begin{array}{c}0.00019 \\
(0.00002)^{* * *}\end{array}$ & $\begin{array}{c}0.00015 \\
(0.00003) * * *\end{array}$ & $\begin{array}{c}0.00007 \\
(0.00001)^{* * *}\end{array}$ & $\begin{array}{c}0.00019 \\
(0.00002)^{* * *}\end{array}$ \\
\hline $\begin{array}{l}\text { Elasticity of FDI to air } \\
\text { frequencies }\end{array}$ & $\begin{array}{c}0.19 \\
(0.02)^{* * * *} \\
\end{array}$ & $\begin{array}{c}0.16 \\
(0.03)^{* * *} \\
\end{array}$ & $\begin{array}{c}0.19 \\
(0.02)^{* * *} \\
\end{array}$ & $\begin{array}{c}0.15 \\
(0.03)^{* * *} \\
\end{array}$ & $\begin{array}{c}0.07 \\
(0.01)^{* * *} \\
\end{array}$ & $\begin{array}{c}0.19 \\
(0.02)^{* * *} \\
\end{array}$ \\
\hline Controls & ALL & ALL & ALL & ALL & ALL & ALL \\
\hline $\begin{array}{c}\mathrm{R}^{2} \\
\text { Number observations }\end{array}$ & $\begin{array}{l}0.46 \\
1134\end{array}$ & $\begin{array}{l}0.46 \\
1134\end{array}$ & $\begin{array}{l}0.48 \\
891\end{array}$ & $\begin{array}{l}0.48 \\
891\end{array}$ & $\begin{array}{l}0.43 \\
891\end{array}$ & $\begin{array}{l}0.41 \\
891\end{array}$ \\
\hline
\end{tabular}

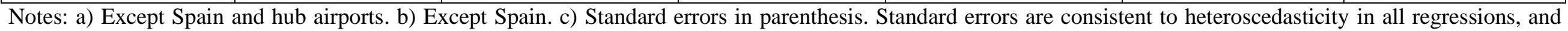

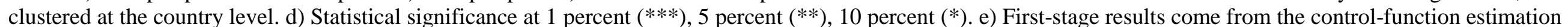
because the GMM procedure does not report them. 
TABLE 5. Results of the estimates (PPML) - Inward \& outward

\begin{tabular}{|c|c|c|}
\hline Dependent variable & Inward FDI & Outward FDI \\
\hline Air frequencies & $0.00027(0.000055)^{* * *}$ & $0.00011(0.00005)^{* * *}$ \\
\hline $\begin{array}{c}\text { Elasticity of FDI to air } \\
\text { frequencies }\end{array}$ & $0.26(0.05)^{* * *}$ & $0.11(0.05)^{* * *}$ \\
\hline \multicolumn{3}{|l|}{ Controls } \\
\hline Population & $0.0036(0.0004)^{* * *}$ & $0.003(0.0007)^{* * *}$ \\
\hline $\begin{array}{l}\text { Gross domestic product per } \\
\text { capita }\end{array}$ & $0.00003(7.64 \mathrm{e}-06)^{* * *}$ & $0.000018(7.26 \mathrm{e}-06)^{* *}$ \\
\hline Distance & $-0.00043(0.000011) * * *$ & $-0.00029(0.00014)^{* * *}$ \\
\hline Gross domestic product (growth) & $-0.17(0.03)^{* * *}$ & $-0.03(0.03)$ \\
\hline Openess & $0.009(0.0019)^{* * *}$ & $-0.0005(0.002)$ \\
\hline Burden Tax & $-0.85(0.16)^{* * *}$ & $-0.68(0.14)^{* * *}$ \\
\hline Time zone & $0.34(0.16)^{* *}$ & $0.04(0.18)$ \\
\hline Exchange rate & $-0.21(0.36)$ & $0.69(0.27)^{* * *}$ \\
\hline Broadband & $0.06(0.02) * * *$ & $0.05(0.02)^{* * *}$ \\
\hline Credit & $0.0003(0.002)$ & $-0.001(0.002)$ \\
\hline $\mathrm{D}^{\text {North_America }}$ & $1.54(1.07)$ & $1.69(1.16)$ \\
\hline $\mathrm{D}^{\text {Latin American \& Caribbean countries }}$ & $2.40(1.36)^{*}$ & $2.81(0.26)^{* *}$ \\
\hline $\mathrm{D}^{\text {Near \& Middle East }}$ & $0.76(0.97)$ & $-0.81(0.67)$ \\
\hline $\mathrm{D}^{\text {Far east }}$ & $-1.09(1.93)$ & $0.22(1.57)$ \\
\hline $\mathrm{D}^{\text {Post-soviet_states }}$ & $0.87(0.55)$ & $-0.76(0.56)$ \\
\hline $\mathrm{D}^{\text {Maghreb }}$ & $-1.92(0.54) * * *$ & $-0.09(0.61)$ \\
\hline Intercept & $5.66(0.89)^{* * *}$ & $8.87(0.97)^{* * *}$ \\
\hline Year fixed effects & YES & YES \\
\hline $\begin{array}{c}\mathrm{R}^{2} \\
\text { Number observations }\end{array}$ & $\begin{array}{l}0.46 \\
1134\end{array}$ & $\begin{array}{l}0.29 \\
1134\end{array}$ \\
\hline
\end{tabular}

Notes: a) Standard errors in parenthesis. Standard errors are consistent to heteroscedasticity in all regressions, and clustered at the country level. b) Statistical significance at 1 percent $(* * *), 5$ percent $(* *), 10$ percent $(*)$. c) Instrument of air frequencies is air frequencies to European airports (except Spain and hub airports). 
TABLE 6. Results of the estimates (PPML) - different controls

\begin{tabular}{|c|c|c|c|c|c|}
\hline \multirow{2}{*}{$\begin{array}{c}\text { Dependent variable } \\
\text { Air frequencies }\end{array}$} & \multicolumn{5}{|c|}{ Total FDI } \\
\hline & $0.00020(0.00002)^{* * *}$ & $0.00018(0.00002) * * *$ & $0.00012(0.00002) * * *$ & $0.00016(0.00003) * * *$ & $0.00017(0.00007)^{* * *}$ \\
\hline $\begin{array}{l}\text { Elasticity of FDI to air } \\
\text { frequencies }\end{array}$ & $0.20(0.02)^{* * *}$ & $0.17(0.02)^{* * *}$ & $0.12(0.02)^{* * *}$ & $0.15(0.03)^{* * *}$ & $0.17(0.07)^{* * *}$ \\
\hline \multicolumn{6}{|l|}{ Controls } \\
\hline Population & $0.0012(0.0001)^{* * *}$ & $0.0022(0.0004)^{* * *}$ & $0.002(0.0003) * * *$ & $0.003(0.0003)^{* * *}$ & $0.003(0.0003)^{* * *}$ \\
\hline $\begin{array}{c}\text { Gross domestic product per } \\
\text { capita }\end{array}$ & $0.00003(2.92 \mathrm{e}-06) * * *$ & $0.00003(3.59 \mathrm{e}-06) * * *$ & $0.00003(4.35 \mathrm{e}-06) * * *$ & - & $0.00002(5.77 \mathrm{e}-06) * * *$ \\
\hline $\begin{array}{l}\text { Gross domestic product per } \\
\text { capita (three lags) }\end{array}$ & - & - & - & $0.00003(7.18 \mathrm{e}-06)^{* * *}$ & - \\
\hline Distance & $-0.000015(0.00003) * * *$ & $-0.0003(0.0001) * * *$ & $-0.00014(0.0001)$ & $-0.0002(0.0001)^{* * *}$ & $-0.0003(0.00001)^{* * *}$ \\
\hline $\begin{array}{l}\text { Gross domestic product } \\
\text { (growth) }\end{array}$ & - & - & $-0.09(0.02)^{* * *}$ & $-0.06(0.02)^{* *}$ & $-0.06(0.02)^{* *}$ \\
\hline Openess & - & - & $0.0003(0.0011)$ & $0.002(0.001)^{*}$ & $0.003(0.001)^{* *}$ \\
\hline Burden Tax & - & - & $0.23(0.15)$ & $-0.30(0.14)^{* *}$ & $-0.30(0.15)^{* *}$ \\
\hline Time zone & - & - & $0.26(0.13) * *$ & $0.07(0.14)$ & $0.09(0.14)$ \\
\hline Exchange rate & - & - & $0.9(0.2) * * *$ & $0.5(0.2)^{* *}$ & $0.46(0.22) * *$ \\
\hline Broadband & - & - & $0.02(0.01)^{*}$ & $0.02(0.01)^{*}$ & $0.02(0.01)^{*}$ \\
\hline Credit & - & - & $-0.004(0.02)^{* * *}$ & $-0.001(0.001)$ & $-0.0008(0.001)$ \\
\hline Broadband x Air frequencies & & - & - & - & $-5.76 \mathrm{e}-07(2.09 \mathrm{e}-06)$ \\
\hline $\mathrm{D}^{\text {North_America }}$ & - & $2.12(0.47)^{* * *}$ & - & $1.79(0.82)^{* *}$ & $1.82(0.84)^{* *}$ \\
\hline $\mathrm{D}^{\text {Latin American \& Caribbean countries }}$ & - & $2.76(0.63) * * *$ & - & $3.00(0.93) * * *$ & $3.13(0.87) * * *$ \\
\hline $\mathrm{D}^{\text {Near \& Middle East }}$ & - & $-0.72(0.36)^{* *}$ & - & $-0.21(0.54)$ & $-0.14(0.52)$ \\
\hline $\mathrm{D}^{\text {Far east }}$ & - & $2.46(0.81)^{* * *}$ & - & $0.36(1.15)$ & $0.29(1.16)$ \\
\hline $\mathrm{D}^{\text {Post-soviet_states }}$ & - & $-0.94(0.35)^{* * *}$ & - & $-0.14(0.46)$ & $-0.11(0.47)$ \\
\hline $\mathrm{D}^{\text {Maghreb }}$ & - & $-0.52(0.55)$ & - & $0.14(0.59)$ & $0.21(0.63)$ \\
\hline Intercept & $9.95(0.30)^{* * *}$ & $8.85(0.41)^{* * *}$ & $9.06(0.69) * * *$ & $8.50(0.68)^{* * *}$ & $8.47(0.77)^{* * *}$ \\
\hline Year fixed effects & YES & YES & YES & YES & YES \\
\hline $\begin{array}{c}\mathrm{R}^{2} \\
\text { Number observations }\end{array}$ & $\begin{array}{l}0.37 \\
1134\end{array}$ & $\begin{array}{l}0.41 \\
1134\end{array}$ & $\begin{array}{l}0.42 \\
1134\end{array}$ & $\begin{array}{l}0.46 \\
1134\end{array}$ & $\begin{array}{l}0.46 \\
1134\end{array}$ \\
\hline
\end{tabular}

Notes: a) Standard errors in parenthesis. Standard errors are consistent to heteroscedasticity in all regressions, and clustered at the country level. b) Statistical significance at 1 percent $(* * *), 5$ percent $(* *), 10$ percent $(*)$. c) Instrument of air frequencies are Air frequencies to EU airports (except Spanish airports and hub airports) 
TABLE 7. Results of the estimates (PPML) -different sub-samples

\begin{tabular}{|c|c|c|c|}
\hline Dependent variable & \multicolumn{3}{|c|}{ Total FDI } \\
\hline Sub sample & $\begin{array}{l}\text { Observations with } \\
\text { positive values in } \\
\text { FDI and air } \\
\text { frequencies }\end{array}$ & EU countries excluded & $\begin{array}{c}\text { Countries with several } \\
\text { cities having non-stop } \\
\text { flights to Barcelona } \\
\text { excluded }\end{array}$ \\
\hline Air frequencies & $0.20(0.05)^{* * *}$ & $0.004(0.00056) * * *$ & $0.0003(0.00006)^{* * *}$ \\
\hline $\begin{array}{l}\text { Elasticity of FDI to air } \\
\text { frequencies }\end{array}$ & - & $0.66(0.09)^{* * *}$ & $0.09(0.02)^{* * *}$ \\
\hline \multicolumn{4}{|l|}{ Controls } \\
\hline Population & $0.03(0.03)$ & $0.003(0.00003) * * *$ & $0.003(0.0003)^{* * *}$ \\
\hline $\begin{array}{l}\text { Gross domestic product per } \\
\text { capita }\end{array}$ & $0.02(0.05)$ & $0.00001(0.00001)$ & $0.00002(6.83 \mathrm{e}-06) * * *$ \\
\hline Distance & $0.11(0.09)$ & $7.12 \mathrm{e}-07(0.00007)$ & $-0.0001(0.00007)^{* * *}$ \\
\hline Gross domestic product (growth) & $0.002(0.006)$ & $-0.04(0.03)$ & $-0.06(0.03)^{*}$ \\
\hline Openess & $0.22(0.05) * * *$ & $0.001(0.001)$ & $0.005(0.001)^{* * *}$ \\
\hline Burden Tax & $-0.003(0.02)$ & $-0.83(0.17)^{* * *}$ & $-0.54(0.31)^{*}$ \\
\hline Time zone & $-0.08(0.02)^{* * *}$ & $-0.46(0.09)^{* * *}$ & $-0.19(0.13)$ \\
\hline Exchange rate & $0.03(0.01)^{*}$ & $-0.76(0.30)^{* * *}$ & $0.79(0.24)^{* * *}$ \\
\hline Broadband & $-0.03(0.02)$ & $0.12(0.02)^{* * *}$ & $0.06(0.01)^{* * *}$ \\
\hline Credit & $0.05(0.03)^{*}$ & $0.007(0.002)^{* * *}$ & $-0.00013(0.0018)$ \\
\hline $\mathrm{D}^{\text {North_America }}$ & $0.63(0.15)^{* * *}$ & - & - \\
\hline $\mathrm{D}^{\text {Latin American \& Caribbean countries }}$ & $0.82(0.13)^{* * *}$ & $5.69(0.51)^{* * *}$ & $4.39(0.78) * * *$ \\
\hline $\mathrm{D}^{\text {Near \& Middle East }}$ & $0.07(0.06)$ & $1.31(0.35)^{* * *}$ & $0.64(0.59)$ \\
\hline $\mathrm{D}^{\text {Far east }}$ & $0.20(0.19)$ & $1.90(0.61)^{* * *}$ & $0.94(1.07)$ \\
\hline $\mathrm{D}^{\text {Post-soviet_states }}$ & $0.03(0.09)$ & $-0.30(0.48)$ & $-1.29(0.69)^{*}$ \\
\hline $\mathrm{D}^{\text {Maghreb }}$ & $0.07(0.08)$ & $1.68(0.514)^{* * * *}$ & $-2.22(0.91)^{* * *}$ \\
\hline Intercept & $-1.50(0.74)^{* *}$ & $7.34(0.85)^{* * *}$ & $8.96(0.86)^{* * *}$ \\
\hline Year fixed effects & YES & YES & YES \\
\hline $\begin{array}{c}\mathrm{R}^{2} \\
\text { Number observations }\end{array}$ & $\begin{array}{l}0.54 \\
550\end{array}$ & $\begin{array}{l}0.45 \\
771\end{array}$ & $\begin{array}{l}0.43 \\
939\end{array}$ \\
\hline
\end{tabular}

Notes: a) Standard errors in parenthesis. Standard errors are consistent to heteroscedasticity in all regressions, and clustered at the country level. b) Statistical significance at 1 percent $(* * *), 5$ percent $(* *)$, 10 percent $(*)$. c) Instrument of air frequencies is air frequencies to European airports (except Spain and hub airports). d) In the regression with EU countries excluded, North America is the geographical area of reference. In the regression for observations with no zeros in FDI and air frequencies and the regression that excludes countries with several cities having non-stop flights, the geographical area of reference is the European Economic Area. e) In the regression for observations with positive values in FDI and air frequencies, all continuous variables are in logs. f) I use the control-function estimator in the regression with EU countries excluded because the GMM estimator does not converge to any value. 
TABLE 8. Results of the estimates (PPML) -Sample including Madrid

\begin{tabular}{|c|c|c|c|}
\hline Dependent variable & \multicolumn{3}{|c|}{ Total FDI } \\
\hline Sample & Madrid as endpoint & $\begin{array}{l}\text { Madrid \& Barcelona } \\
\text { as endpoints }\end{array}$ & $\begin{array}{l}\text { Madrid \& Barcelona } \\
\text { as endpoints (with } \\
\text { destination countries } \\
\text { fixed effects) }\end{array}$ \\
\hline Air frequencies & $0.00029(0.00007)^{* * * *}$ & $0.00028(0.00003)^{* * *}$ & $0.0008(0.0004)^{* *}$ \\
\hline $\begin{array}{l}\text { Elasticity of FDI to air } \\
\text { frequencies }\end{array}$ & $0.38(0.09)^{* * *}$ & $0.32(0.04)^{* * *}$ & $0.90(0.46)^{* *}$ \\
\hline \multicolumn{4}{|l|}{ Controls } \\
\hline Population & $0.0026(0.001)^{* * *}$ & $0.002(0.0003)^{* * *}$ & $0.003(0.005)$ \\
\hline $\begin{array}{l}\text { Gross domestic product } \\
\text { per capita }\end{array}$ & $6.80 \mathrm{e}-06(8.72 \mathrm{e}-06) * * *$ & $0.00004(6.34 \mathrm{e}-06) * * *$ & $0.00006(0.00001)^{* * *}$ \\
\hline Distance & $-0.0001(0.0001)$ & $-0.0003(0.00006)^{* * *}$ & - \\
\hline $\begin{array}{l}\text { Gross domestic product } \\
\text { (growth) }\end{array}$ & $-0.08(0.04)^{* *}$ & $-0.06(0.02)^{* * *}$ & $-0.01(0.01)$ \\
\hline Openess & $0.01(0.004)^{* * *}$ & $0.0007(0.0011)$ & $0.005(0.004)$ \\
\hline Burden Tax & $-0.67(0.30)^{* * *}$ & $-0.87(0.16)^{* * *}$ & - \\
\hline Time zone & $0.05(0.21)$ & $-0.49(0.08)^{* * *}$ & - \\
\hline Exchange rate & $0.81(0.36)^{* *}$ & $-0.62(0.25)^{* * *}$ & $-1.06(0.53)^{* *}$ \\
\hline Broadband & $0.01(0.02)$ & $0.01(0.01)$ & $-0.05(0.01)^{* * *}$ \\
\hline Credit & $0.01(0.005)^{* *}$ & $0.008(0.002)^{* * *}$ & $0.003(0.003)$ \\
\hline $\mathrm{D}^{\text {North_America }}$ & $1.27(1.01)$ & $3.11(0.47)^{* * *}$ & - \\
\hline $\begin{array}{l}\mathrm{D}^{\text {Latin American \& Caribbean }} \\
\text { countries }\end{array}$ & $3.47(0.95)^{* * *}$ & $5.61(0.58)^{* * *}$ & - \\
\hline $\mathrm{D}^{\text {Near \& Middle East }}$ & $1.01(1.16)$ & $0.47(0.27) * * *$ & - \\
\hline $\mathrm{D}^{\text {Far east }}$ & $-2.06(1.89)$ & $3.41(0.75)^{* * *}$ & - \\
\hline $\mathrm{D}^{\text {Post-soviet_states }}$ & $0.85(1.17)$ & $-1.27(0.34)^{* * *}$ & - \\
\hline $\mathrm{D}^{\text {Maghreb }}$ & $1.26(1.23)$ & $0.44(0.42)$ & - \\
\hline $\mathrm{D}^{\text {Barcelona }}$ & - & $-1.21(0.12)^{* * *}$ & $-0.87(0.18)^{* * *}$ \\
\hline Intercept & $7.89(1.89)^{* * *}$ & $12.81(0.60)^{* * *}$ & $8.91(0.62)^{* * *}$ \\
\hline Year fixed effects & YES & YES & YES \\
\hline $\begin{array}{c}\mathrm{R}^{2} \\
\text { Number observations }\end{array}$ & $\begin{array}{l}0.41 \\
1134\end{array}$ & $\begin{array}{l}0.39 \\
2268\end{array}$ & $\begin{array}{c}0.51 \\
2268\end{array}$ \\
\hline
\end{tabular}

Notes: a) Standard errors in parenthesis. Standard errors are consistent to heteroscedasticity in all regressions, and clustered at the country level. b) Statistical significance at 1 percent $(* * *), 5$ percent $(* *), 10$ percent $(*)$. c) Instrument of air frequencies is air frequencies to European airports (except Spain and hub airports). d) I use the control-function estimator in the regression with Madrid and Barcelona as endpoints because the GMM estimator does not converge to any value. 